\title{
dosalgarves
}

\section{Determinants of capital structure: New evidence from Portuguese small firms}

\author{
Determinantes da estrutura de capital: Evidências das pequenas \\ empresas portuguesas
}

\author{
Zélia Serrasqueiro \\ Universidade da Beira Interior, Covilhã, Portugal \\ zelia@ubi.pt \\ Fernanda Matias \\ Universidade do Algarve, Faro, Portugal \\ mfmatias@ualg.pt \\ Leonor Salsa \\ Universidade do Algarve, Faro, Portugal \\ mlsalsa@ualg.pt
}

\begin{abstract}
This paper studies the determinants of capital structure of 2,329 Portuguese small firms, decomposing total liabilities in long and short-term debt. The results of 2007-2011 panel data suggest that information asymmetry and agency problems seem to be important for small firms in accessing long-term debt. Greater size and a higher level of collateral are quite important in accessing long-term debt. Liquidity is positively associated with long-term debt, although it is negatively related to short-term debt. Higher profitability is related to lower levels of debt. When internal finance is insufficient, these firms seem to be strongly dependent on short-term debt, due to the difficulties in accessing long-term. The main conclusion of the current study is that the predicitons of POT and TOT are followed by small firms in their capital structure, which is in accordance with the results of previous studies focusing on SMEs.
\end{abstract}

Keywords: capital structure; panel data models; small firms.

\section{Resumo}

\begin{abstract}
Neste trabalho, analisamos os determinantes do endividamento das pequenas empresas portuguesas, utilizando os modelos de dados em painel e decompondo a dívida em médio/longo prazo e curto prazo. Os resultados obtidos sugerem que a informação assimétrica e os problemas de agência influenciam o acesso à dívida de longo prazo por parte destas empresas, assim como a dimensão e o nível de colateral. A liquidez está positivamente associada com a dívida de longo prazo e negativamente com a de curto prazo. Maior rendibilidade está relacionada com menor endividamento. Quando os fundos internos são insuficientes, as empresas parecem estar fortemente dependentes da dívida de curto prazo, dadas as dificuldades no acesso à de longo prazo. A principal conclusão deste trabalho é a de que os pressupostos da pecking-order theory e da trade-off theory se aplicam à estrutura de capital das pequenas portuguesas, o que está de acordo com os resultados obtidos em estudos anteriores sobre PME.
\end{abstract}

Palavras-chave: estrutura de capital; dados em painel; pequenas empresas.

Dos Algarves: A Multidisciplinary e-Journal, 28 - 2016.

ISBN 2182-5580 ๑ ESCHT-University of the Algarve, Portugal.

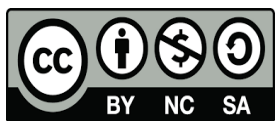

To cite this article: Serrasqueiro, Z., Matias, F. \& Salsa, L. (2016). Determinants of capital structure: New evidence from Portuguese small firms. Dos Algarves: A Multidisciplinary e-Journal, 28, 13-28. doi: 10.18089/DAMeJ.2016.28.2 


\section{Introduction}

After publication of the famous work by Modigliani and Miller (1958), the topic of capital structure has inspired many researchers. Firms' capital structure decisions are one of the most researched topics in corporate finance. Modigliani and Miller (1958) argue that, under a set of assumptions (complete and perfect capital markets), capital structure does not affect firm value. Removing one or more of Modigliani and Miller's assumptions, many theories of capital structure have been proposed. Trade-off theory (hereafter TOT) and pecking-order theory (hereafter POT) are the main theories used to explain firms' financing decisions.

Micro and small firms face greater restrictions in obtaining external finance, namely a greater rejection rate of bank loans, and higher interest rates in comparison to larger firms (Doove, Gibcus, Kwaak, Smit \& Span, 2014). Beck, Demirgüç-Kunt, Laeven and Maksimovic (2006), analysing USA firms, conclude that firm size is negatively related to the obstacles in accessing external finance. Besides the literature showing that firm size is a determinant of capital structure, the majority of studies analyze Small and Medium-Sized Enterprises (SMEs) as a whole, with the exception of some studies (López-Gracia \& Aybar-Arias, 2000; Heshmati, 2001; Psillaki \& Daskalakis, 2009). The main objective of this paper is to test trade-off and pecking-order theories in the field of small firms, taking into account their particular characteristics. Additionally, considering the arguments of several authors (Chittenden, Hall \& Hutchinson, 1996; Bevan \& Danbolt, 2004) that analysis of capital structure determinants based on total debt may mask significant differences between longterm and short-term debt, we also analyse the determinants of short-term and long-term debt.

In 2008, 343,151 of the 350,871 Portuguese non-financial firms were micro and small firms, providing $53 \%$ of total employment and representing $36.3 \%$ of total turnover (Instituto Nacional de Estatística [INE], 2010). To reach the objective of this study, we consider a sample of 2,329 small Portuguese firms with data taken from the Amadeus database, for the period between 2007 and 2011. As method of estimation, we use fixed effect panel data models. The results obtained show the existence of a negative relationship between profitability and debt, suggesting that small firms follow the predictions of POT in their capital structure decisions. Furthermore, a positive relationship was identified between size and debt, which can be interpreted in accordance with the predictions of TOT. In the current study, small firms with higher levels of liquidity seem to have higher levels of longterm debt, probably due to more favourable conditions in obtaining long-term debt. In general, the results suggest that POT and TOT are not mutually exclusive in explaining the capital structure decisions of small firms.

The remainder of this paper is organized as follows. In section 2, the literature review is presented and research hypotheses are formulated. Section 3 presents the methodology used. The results are presented in section 4. Finally, section 5 presents the conclusion and implications.

\section{Literature review and research hypotheses}

Recent research on firms' capital structure has been synthesized into the frameworks of TOT and POT. TOT includes fiscal issues, financial distress and conflicts of interest. It 
assumes that firms have a target debt level (Taggart, 1977; Jalilvand \& Harris, 1984). Various authors (López-Gracia \& Sánchez-Andújar, 2007; López-Gracia \& Sogorb-Mira, 2008) consider that the target debt ratio depends on a firm's characteristics. TOT predicts an optimal capital structure that maximizes the advantages of debt tax-shields and minimizes bankruptcy costs (Shyam-Sunder \& Myers, 1999; Fama \& French, 2002; Frank \& Goyal, 2008). Debt allows firms to benefit from debt tax-shields (Modigliani \& Miller, 1963; DeAngelo \& Masulis, 1980) and reduce the free cash flow problem between managers and shareholders (Jensen \& Meckling, 1976; Jensen, 1986; Stulz, 1990). However, there are disadvantages associated with debt: agency costs, which arise mainly from the potential conflicts between managers/owners and creditors (Jensen \& Meckling, 1976; Myers, 1977) and financial distress costs (Robichek \& Myers, 1966; Kraus \& Litzenberger, 1973; Scott, 1976; Kim, 1978).

POT, proposed by Myers (1984) and Myers and Majluf (1984), provides a theoretical foundation for the proposition of Donaldson's 1961 study, regarding the financing practices of a sample of large firms. Donaldson concludes that firms, in the long-term, establish a growth rate compatible with the generation of internal funds (Donaldson, 1961).

In accordance with POT, firms do not intend to reach an optimal debt ratio. Instead, capital structure is the result of cumulative funding needs. Firms follow a hierarchical order in the choice of financing sources, which is based on funding costs. Asymmetric information and agency problems between managers/owners and external investors generate costs (Hall, Hutchinson \& Michaelas, 2000). Therefore, firms would prefer to use internal funds, followed by debt. When those financing sources are exhausted, firms will issue equity.

According to Holmes and Kent (1991), the majority of small firms do not issue equity, because they are outside the stock market and their owners are reluctant to open up the firm's capital to external investors, to avoid diluting their ownership interest and control.

Beck, Demirgüç-Kunt and Maksimovic (2008) investigated whether the financing patterns of small firms differ from those of large firms. Using a firm-level survey database, covering 48 countries ( $80 \%$ of observations concern SMEs), their results show that small firms finance their investments through a lower proportion of external finance. Many small firms begin their activities undercapitalized with inadequate financial resources. Additionally, small firms, unlike their larger counterparts, are unable to raise capital in the public debt and equity markets (Ang, 1991).

Subsequently, we analyse the determinants of small firms' capital structure decisions as well as their relationships with capital structure theories.

\subsection{Firm size}

In accordance with TOT, firm size is positively associated with the level of leverage. Taking bankruptcy costs into account, Scott (1976) argues that larger firms are more prone to obtain debt, because they have a high value of assets granting their capacity to pay off the debt and interest. Furthermore, larger firms are more diversified, implying a lower risk for creditors (Ang, 1992). Considering the scale effect of bankruptcy costs, Gruber and Warner (1977) and Ang, Chua and McConnell (1982) argue that those costs tend to be lower for larger firms.

Barnea, Haugen and Senbet (1981) argue that agency problems will tend to be more severe whenever the level of asymmetric information is greater. Problems of asymmetric 
information and moral hazard will be greater for small firms, because of the lack of financial disclosure and their owner-managed nature. Therefore, lenders will be unwilling to lend long-term to small firms on favourable terms (Chittenden et al., 1996). To overcome those problems, SMEs tend to issue short-term debt (Heyman, Deloof \& Ooghe, 2008). Pettit and Singer (1985) argue that debt costs may be higher for small firms, but equity costs are even higher for those firms than for larger firms. Consequently, small firms frequently have a higher level of short-term debt than larger firms.

The existence of asymmetric information between lenders and borrowers is one of the most common imperfections in the credit market. This is more problematic in small firms due to the poor quality of their financial information (López-Gracia \& Aybar-Arias, 2000). Empirical studies on the capital structure of small firms have identified a positive relationship between firm size and total leverage (Sogorb-Mira 2005; Serrasqueiro, Armada \& Nunes, 2011; Degryse, Goeij \& Kappert, 2012). Several authors (Chittenden et al., 1996; Michaelas, Chittenden \& Poutziouris, 1999; Hall, Hutchinson \& Michaelas, 2004) find a negative effect of firm size on short-term debt, but other studies (Michaelas, Chittenden \& Poutziouris, 1999; Bhaird \& Lucey, 2010; Degryse et al., 2012) identify a positive relationship between size and long-term debt.

Hypothesis 1: Firm size is positively related to debt.

Hypothesis 1a: Firm size is positively related to long-term debt.

Hypothesis 1b: Firm size is negatively related to short-term debt.

\subsection{Asset Structure}

According to Myers (1993), distress costs are directly affected by a firm's asset structure, given that tangible assets support more debt than intangible assets. Harris and Raviv (1990) argued that a higher value of tangible assets is related to greater debt capacity. Tangible assets can be used as collateral in the case of firm bankruptcy, protecting creditors' rights. Apart from this advantage, tangible assets may also be used to reduce agency problems (Degryse et al., 2012). Michaelas et al. (1999) claim that firms with valuable tangible assets, which can be used as collateral, have easier access to debt and probably higher levels of debt than firms with low levels of tangible assets.

Asset tangibility also mitigates problems of information asymmetry. POT predicts a positive relationship between asset tangibility and leverage, considering that a higher level of tangible assets increases the possibility of collateral and lessens problems of information asymmetry between SMEs managers/owners and creditors (Michaelas et al., 1999; SogorbMira, 2005).

Empirical studies on the capital structure of small firms tend to find a positive relationship between asset tangibility and total leverage (Sogorb-Mira 2005; Serrasqueiro et al., 2011; Degryse et al., 2012). Several authors identify a negative effect of asset tangibility on short-term debt but a positive one on long-term debt (Chittenden et al., 1996; Hall et al., 2004; Sogorb-Mira 2005).

Hypothesis 2: Tangible assets are positively related to debt.

Hypothesis 3: Tangible assets have a stronger positive effect on long-term debt than on short-term debt. 


\subsection{Liquidity}

TOT predicts a positive relationship between liquidity and leverage. Bankruptcy costs tend to be higher for firms with low levels of liquidity, and so they will face more obstacles in obtaining debt (Degryse et al., 2012). According to POT, there is a negative relationship between debt and liquidity, because firms with high levels of liquidity have more internal funds, and therefore tend to borrow less. De Jong, Kabir and Nguyen (2008) consider that in the presence of asymmetric information, accumulated cash and other liquid assets serve as internal sources of funding that firms will use first instead of debt.

Hypothesis 4: Liquidity is negatively related to debt.

\subsection{Profitability}

According to TOT, the most profitable firms have greater debt capacity, and can take advantage of debt tax-shields (MacKie-Mason, 1990; Fama \& French, 2002). The most profitable firms are probably more able to fulfil their responsibilities, regarding the repayment of debt and interest, which contributes to less likelihood of bankruptcy.

On the contrary, POT predicts an inverse relationship between profitability and the level of debt. According to POT, profitable firms will finance their investments with internal funds. They move to external finance only when internal funding is insufficient. Additionally, firms prefer debt to equity (Myers, 1984; Chittenden et al. 1996). Michaelas et al. (1999), using panel data for U.K. small firms over a ten-year period (1986-1995), find that profitability affects the structure of debt maturity in SMEs, providing evidence of the preference for short-term financing over long-term in small businesses.

These empirical studies on capital structure determinants found a negative relationship between profitability and debt ratio.

Hypothesis 5: Profitabiblity is negatively related to debt.

\subsection{Growth opportunities}

TOT predicts a negative relationship between growth opportunities and leverage. As shown by Myers (1977), the underinvestment problem becomes more acute in firms with high levels of growth opportunities. Myers (1977) argues that firms with high levels of investment opportunities face difficulties in obtaining debt because the expected costs of financial distress are higher for firms in this situation. Firms with greater growth opportunities have a lower level of debt, given that these firms face higher agency problems between managers/owners and creditors, because the former have great incentives to under-invest (Myers, 1977; Smith \& Warner, 1979). Additionally, according to TOT, growth opportunities have no value in the case of firm bankruptcy, and so bankruptcy costs associated with recourse to debt are greater in firms with high growth opportunities.

Firms with higher growth opportunities have greater funding needs. In accordance with POT, when internal finance is exhausted, firms prefer debt to external equity to fund growth opportunities associated with a greater risk than investment in assets in place (Baskin 1989; Shyam-Sunder \& Myers, 1999; Ramalho \& Silva, 2009). These authors state 
that firms with good growth opportunities increase debt when internal funds are insufficient. Therefore, POT forecasts a positive relationship between growth opportunities and debt. Empirical studies on SMEs tend to identify a positive relationship between growth opportunities and leverage (Michaelas et al., 1999; Degryse et al., 2012).

Hypothesis 6: Growth opportunities are positively related to debt.

\subsection{Taxes}

According to Modigliani and Miller (1963), in the presence of tax on corporate income, firms should fund as much as possible of their investment through debt (greater marginal tax rate implies greater tax benefits). Those authors consider that debt generates tax-shields, but ignore important aspects, namely, that firms can obtain tax benefits alternatively to debt tax-shields and that debt increases the probability of bankruptcy. However, firms may increase their leverage ratio until the level that does not significantly increase the inherent costs of financial distress. In this framework, Scott (1976) argues for a positive relationship between level of debt and corporate tax rate.

Constand, Osteryoung and Nast (1991) and Michaelas et al. (1999) found no significant effects of corporate tax on level of leverage. Degryse et al. (2012) conclude that the tax rate has a significant negative effect on total and long-term debt, but a slightly positive effect on short-term debt.

Hypothesis 7: Effective tax rate is positively related to debt.

\subsection{Non-debt tax shields}

According to DeAngelo and Masulis (1980), non-debt tax shields, such as deductions allowed by depreciation and amortization as well as investment tax credit could substitute the role of tax savings permitted by debt. This implies that a firm with a high level of nondebt tax shields will probably have a lower level of debt than a firm with low non-debt tax shields. TOT forecasts a negative relationship between non-debt tax shields and debt. Constand et al. (1991) and Degryse et al. (2012) do not identify a significant effect of nondebt tax shields on debt ratio. However, Jordan, Lowe and Taylor (1998) and Michaelas et al. (1999) conclude that non-debt tax shields have a negative effect on total debt.

Hypothesis 8: Non-debt tax shields are negatively related to debt.

\section{Methodology}

\subsection{Database and variables}

In the present study we use data gathered from the Amadeus database supplied by Bureau van Dijk's, containing economic and financial information on European firms. The firms forming the research sample meet the definition established by the European Commission for small firms (Commission of the European Communities [CEC], 2003, Recommendation Nr. C(2003) 1422), according to which, a business unit is considered a small firm when: i) it 
employs fewer than 50 people; and ii) its turnover or total annual balance sheet does not exceed $€ 10$ million.

We remove financial and insurance firms (due to their specific financial behaviour and uniqueness), and firms without employees or turnover. We remove all entries which show unreasonable values, namely, when the percentage of fixed assets over total assets exceeds $100 \%$ and/or equity presents negative values. The data set has been restricted to observations including all the variables, and also where these variables have a complete record over the period of analysis. The final sample contains 2,329 small firms. The data obtained refers to the period from 2007 to 2011, and so we have a panel made up of 11,645 observations. Table 1 presents the research variables and their respective measures. The proxies of the determinants of capital structure, as independent variables, have been used in various earlier studies (e.g. Degryse et al. 2012).

Table 1. Measurement of variables

\begin{tabular}{|c|c|}
\hline Variables & Measurement \\
\hline $\operatorname{Debt}\left(\mathrm{LEV}_{\mathrm{i}, \mathrm{t}}\right)$ & Ratio between Debt and Total Assets \\
\hline $\begin{array}{l}\text { Short-term Debt }\left(\mathrm{SLE}_{\mathrm{i}, \mathrm{t}}\right) \\
\text { Long-term Debt }\left(\mathrm{LLE}_{\mathrm{i}, \mathrm{t}}\right)\end{array}$ & $\begin{array}{l}\text { Ratio between Short-term Debt and Total Assets } \\
\text { Ratio between Long-term Debt and Total Assets }\end{array}$ \\
\hline $\begin{array}{c}\text { Size }\left(\mathrm{SIZE}_{\mathrm{i}, \mathrm{t}}\right) \\
\text { Liquidity }\left(\mathrm{LIQ}_{\mathrm{i}, \mathrm{t}}\right)\end{array}$ & $\begin{array}{c}\text { Natural logarithm of Total Assets } \\
\text { Ratio between (Debtors-Creditors) and Total Assets }\end{array}$ \\
\hline Asset Structure $\left(\right.$ TANG $\left._{i, t}\right)$ & Ratio between Tangible Assets and Total Assets \\
\hline Profitability $\left(\mathrm{PROF}_{\mathrm{i}, \mathrm{t}}\right)$ & $\begin{array}{l}\text { Ratio between Earnings Before Interest and Taxes and Total } \\
\text { Assets }\end{array}$ \\
\hline Growth Opportunities $\left(\mathrm{GO}_{\mathrm{i}, \mathrm{t}}\right)$ & Ratio between (Total Assets $s_{i, t^{-}}$Total Assets $_{\mathrm{i}, \mathrm{t}-1}$ ) and Total Assets $\mathrm{i}_{\mathrm{i}, \mathrm{t}-1}$ \\
\hline $\begin{array}{c}\text { Effective Tax Paid }\left(\text { TAX }_{i, t}\right) \\
\text { Non-Debt Tax Shields }\left(\text { NDTS }_{i, t}\right)\end{array}$ & $\begin{array}{l}\text { Ratio between Tax Paid and Earnings Before Tax } \\
\text { Ratio between Depreciations and Amortizations and Total Assets }\end{array}$ \\
\hline
\end{tabular}

Source: Authors.

Regarding the proxy of capital structure, we use total debt $\left(\operatorname{LEV}_{i, t}\right)$. Additionally, in order to carry out a decompositional analysis of the total debt ratio, we, also consider as dependent variables, long-term debt $\left(\operatorname{LLE}_{\mathrm{i}, \mathrm{t}}\right)$ and short-term debt $\left(\mathrm{SLE}_{\mathrm{i}, \mathrm{t}}\right)$. Based on the studies mentioned before, debt is measured by its book value and the explanatory variables are the measures presented in Table 1.

\subsection{Estimation model}

The possibility of determining firms' individual effects mitigates the problem of the absence of possible variables relevant in explaining the dependent variable.

Using an OLS regression, firms' non-observable individual effects are not controlled, and heterogeneity, a consequence of not considering those effects, may cause the estimates to be biased and inconsistent (Wooldridge, 2002).

To check the relevance of non-observable individual effects we use the Lagrange Multiplier (LM) test. This tests the null hypothesis of non-relevance of non-observable individual effects, against the alternative hypothesis of relevance of non-observable individual effects. The results of the $L M$ test indicate we can reject the null hypothesis, at $1 \%$ significance. Therefore, an OLS regression will not be the most appropriate way to evaluate 
the relationship between debt and its determinants, since we do not consider the heterogeneity of companies.

However, there may be correlation between firms' non-observable individual effects and debt determinants. Non-observable individual specific effects are identically and independently distributed and do not vary over time. These effects could include managerial incentives, productivity and skills or factors which are specific to the firm, e.g. entry barriers and competitiveness of the industry. If there is no correlation between companies' non-observable individual effects and capital structure determinants, the most appropriate way to evaluate is by using a panel model of random effects. If there is correlation between firms' individual effects and capital structure determinants, the most appropriate estimation method is a panel model admitting the existence of fixed effects. To test for the possible existence of correlation we use the Hausman test. The results of the Hausman test allow us to reject the null hypothesis of absence of correlation between companies' non-observable individual effects and debt determinants, at $1 \%$ significance. In turn, time-specific effects vary over time, but are the same for each firm at any given point in time. These effects include factors that influence firms, namely inflation and interest rates (Sogorb-Mira \& López-Gracia, 2003).

We test for the existence of first and second order autocorrelation, considering estimation of the relationships between determinants and total, short and long-term debt, using fixed effect panel models. The results, whether we consider total, short-term or longterm debt, indicate rejection of the null hypothesis of non-existence of first-order autocorrelation, but we cannot reject the null hypothesis of non-existence of second-order autocorrelation.

Given the relevance of the correlation between non-observable individual effects and the determinants of debt, and the existence of first-order autocorrelation, we may conclude that the most correct way to estimate the relationships between debt determinants is by using a fixed effect panel model, consistent with the existence of firstorder autocorrelation. Thus, estimation of the relationships between determinants and total debt, long-term debt and short-term debt, using panel models of fixed effects, can be presented in the following way:

$$
\begin{gathered}
L E V_{i, t}=\beta_{0}+\beta_{1} \operatorname{NDTS}_{i, t}+\beta_{2} \text { PROF }_{i, t}+\beta_{3} \operatorname{SIZE}_{i, t}+\beta_{4} T_{A N G_{i, t}}+\beta_{5} G O_{i, t}+ \\
\beta_{6} T A X_{i, t}+\beta_{7} L I Q_{i, t}+d_{t}+e_{i, t}+\mu_{i, t} \\
L L E_{i, t}=\beta_{0}+\beta_{1} \operatorname{NDTS}_{i, t}+\beta_{2} \operatorname{PROF}_{i, t}+\beta_{3} \operatorname{SIZE}_{i, t}+\beta_{4} \operatorname{TANG}_{i, t}+\beta_{5} G O_{i, t}+ \\
\beta_{6} T A X_{i, t}+\beta_{7} L_{i, t}+d_{t}+e_{i, t}+\mu_{i, t}
\end{gathered}
$$

$$
\begin{gathered}
S L E_{i, t}=\beta_{0}+\beta_{1} \operatorname{NDTS}_{i, t}+\beta_{2} \operatorname{PROF}_{i, t}+\beta_{3} \operatorname{SIZE}_{i, t}+\beta_{4} \operatorname{TANG}_{i, t}+\beta_{5} G O_{i, t}+ \\
\beta_{6} T A X_{i, t}+\beta_{7} L I Q_{i, t}+d_{t}+e_{i, t}+\mu_{i, t}
\end{gathered}
$$

in which: $i$ represents each of the firms, $t$ represents the period of time, $L E V_{i, t}$ is total debt, $L L E_{i, t}$ is long-term debt, $S L E_{i, t}$ is short-term debt, $N D T S_{i, t}$ is non-debt tax shields, 
$P R O F_{i, t}$ is profitability, $S I Z E_{i, t}$ is size, $T A N G_{i, t}$ is asset structure, $L I Q_{i, t}$ is liquidity, $T A X_{i, t}$ is the effective tax rate, $G O_{i, t}$ corresponds to growth opportunities; $d_{t}$ are year dummy variables that measure the impact of possible macroeconomic alterations on firm debt, $e_{i, t}$ is the error which is assumed to have normal distribution and $\mu_{i, t}$ measures nonobservable effects.

\section{Results}

\subsection{Descriptive statistics and correlation matrix}

The descriptive statistics are presented in Table 2.

Table 2. Descriptive statistics

\begin{tabular}{|c|c|c|c|c|c|}
\hline Variables & Mean & Median & S.D. & Min & Max \\
\hline LEV $_{i, t}$ & 0.62245 & 0.66553 & 0.21914 & 0.00000 & 0.99983 \\
\hline SLE $_{i, t}$ & 0.40985 & 0.39337 & 0.23449 & 0.00000 & 0.99875 \\
\hline LLE $_{i, t}$ & 0.21260 & 0.15297 & 0.21765 & 0.00000 & 0.98875 \\
\hline SIZE $_{i, t}$ & 2.80720 & 2.84030 & 0.53055 & 0.79945 & 4.41602 \\
\hline LIQ $_{i, t}$ & 0.11257 & 0.08229 & 0.22441 & -0.74419 & 0.97584 \\
\hline TANG $_{i, t}$ & 0.40541 & 0.37445 & 0.25028 & 0.00106 & 0.99467 \\
\hline PROF $_{i, t}$ & 0.03937 & 0.03358 & 0.08686 & -1.34730 & 0.80674 \\
\hline CO $_{i, t}$ & 0.10087 & 0.01891 & 0.75853 & -0.86107 & 1.79000 \\
\hline TAX $_{i, t}$ & 0.19218 & 0.19011 & 0.23440 & -0.99375 & 0.99899 \\
\hline NDTS $_{i, t}$ & 0.04889 & 0.03659 & 0.048846 & 0.00000 & 0.99930 \\
\hline
\end{tabular}

Note: Variables are defined in Table 1.

Source: Authors.

According to the results, the main financing source of small Portuguese firms is debt, considering that the average total debt ratio is about $62.25 \%$. These firms have more shortterm than long-term debt ( $66 \%$ of total debt is short-term debt). The results are in accordance with Hall et al. (2004), short-term debt being the main financing source of small Portuguese firms.

Over the period 2007-2011, the average size of small firms is approximately $641,500 €$. The average of tangible assets represents about $41 \%$ of total assets. Average profitability, over the period of analysis, is almost $4 \%$. Growth opportunities average about $10.1 \%$. The average tax rate of Portuguese small firms is about $19 \%$. The average of non-debt tax shields is about $4.9 \%$.

Table 3 shows the results of the correlation matrix. Considering that the correlations presented before are not far from 30\%, the problem of collinearity between independent variables is not particularly relevant in this study (Gujarati \& Porter, 2010/1992). 
Table 3. Correlation matrix

\begin{tabular}{|c|c|c|c|c|c|c|c|c|c|c|}
\hline Variables & $\operatorname{LEV}_{\mathrm{i}, \mathrm{t}}$ & $\mathrm{SLE}_{\mathrm{i}, \mathrm{t}}$ & $\operatorname{LLE}_{\mathrm{i}, \mathrm{t}}$ & SIZE $_{i, t}$ & $\mathrm{LIQ}_{\mathrm{it}}$ & TANG $_{i, t}$ & PROF $_{i, t}$ & $\mathbf{G O}_{\mathrm{i}, \mathrm{t}}$ & $\operatorname{TAX}_{i, t}$ & $\begin{array}{c}\text { NDTS }_{i} . \\
t\end{array}$ \\
\hline LEV $_{i, t}$ & 1 & & & & & & & & & \\
\hline $\mathrm{SLE}_{\mathrm{i}, \mathrm{t}}$ & $0.4468^{*}$ & 1 & & & & & & & & \\
\hline $\operatorname{LLE}_{i, t}$ & $0.5036^{*}$ & $-0.548^{*}$ & 1 & & & & & & & \\
\hline $\mathrm{SIZE}_{\mathrm{i}, \mathrm{t}}$ & $0.358 * *$ & 0.084 & $0.2288^{*}$ & 1 & & & & & & \\
\hline $\mathrm{LIQ}_{\mathrm{it}}$ & $-0.269^{*}$ & $-0.163^{*}$ & $-0.095^{*}$ & 0.035 & 1 & & & & & \\
\hline TANG $_{i, t}$ & $0.3000 *$ & -0.0409 & $0.3200^{*}$ & $0.2216^{*}$ & $-0.355^{*}$ & 1 & & & & \\
\hline PROF $_{i, t}$ & $-0.151^{*}$ & -0.0692 & -0.0743 & -0.0852 & $0.2238^{*}$ & $-0.187^{*}$ & 1 & & & \\
\hline $\mathbf{G O}_{\mathrm{i}, \mathrm{t}}$ & 0.0002 & -0.0086 & 0.0085 & -0.026 & -0.0147 & 0.0493 & 0.0769 & 1 & & \\
\hline $\operatorname{TAX}_{\mathrm{i}, \mathrm{t}}$ & -0.0564 & 0.0778 & $-0.128 *$ & -0.0283 & $0.1167^{*}$ & $0.201^{* *}$ & $0.02905^{*}$ & -0.0524 & 1 & \\
\hline NDTS $_{i, t}$ & $0.0996 *$ & 0.0423 & 0.0423 & $-0.3357^{*}$ & -0.1271 & -0.0524 & 0.0803 & $-0.1137^{*}$ & 0.0701 & 1 \\
\hline
\end{tabular}

Notes: $\quad$ 1. Variables are defined in Table 1.

2. **Statistically significant at $1 \%$ level; * Statistically Significant at $5 \%$ level.

Source: Authors.

\subsection{Determinants of debt and discussion of the results}

Table 4 presents the results of the panel data models, regarding the relationships between determinants and total debt, long-term debt and short-term debt. Analysing the results of the $\mathrm{F}$ test, we conclude that we can reject the null hypothesis that the explanatory variables, together, do not explain the explained variable, and so the determinants selected in this study can be considered explanatory of the debt.

The results show a positive relationship between size and total debt, suggesting that larger firms have greater debt. Furthermore, larger firms seem to rely more on short-term debt as well as long-term debt. Probably, larger firms access long-term debt on more favourable terms due to a greater bargaining power with creditors (Grunert \& Norden, 2012). These results seem a consequence of information assimetry and agency problems, which are particularly important for small firms, contributing to the obstacles they face in accessing debt. Based on these results, we cannot reject hypothesis 1. These results agree with previous studies about SMEs (Sogorb-Mira 2005; Bhaird \& Lucey 2010; Degryse et al. 2012), which conclude that agency problems and asymmetric information in relationships between SMEs and creditors contribute to unfavourable conditions for SMEs when accessing debt.

In this study, we identify positive and statistically significant relationships between long-term debt, short-term debt and size. Therefore, we do not reject sub-hypothesis 1a, corroborating the results of other studies (Michaelas et al., 1999; Bhaird \& Lucey, 2010; Degryse et al., 2012), which identify a positive effect of size on long-term debt. However, we reject sub-hypothesis $1 \mathrm{~b}$, given there is not a negative effect of firm size on short-term debt. Thus, we do not corroborate the results of other studies (Michaelas et al., 1999; Hall et al., 2004; Matias, Baptista \& Salsa, 2015). The results obtained in the current study regarding the relationships between total debt, long-term debt and short-term debt and size are according to the principles of TOT and POT. 
Table 4. Determinants of small firms' capital structure

\begin{tabular}{|c|c|c|c|}
\hline $\begin{array}{c}\text { Independent } \\
\text { Variables }\end{array}$ & $\begin{array}{l}\text { Dependent Variable: } \text { LEV }_{i, t} \\
\text { Fixed Effects AR(1) }\end{array}$ & $\begin{array}{l}\text { Dependent Variable: } \text { LLE }_{i, t} \\
\text { Fixed Effects AR(1) }\end{array}$ & $\begin{array}{l}\text { Dependent Variable: } \mathrm{SLE}_{\mathrm{i}, \mathrm{t}} \\
\text { Fixed Effects AR(1) }\end{array}$ \\
\hline$L I Q_{i, t}$ & $\begin{array}{c}-0.06852 * * * \\
(0.00766)\end{array}$ & $\begin{array}{c}0.04604 * * * \\
(0.01656)\end{array}$ & $\begin{array}{c}-0.12149 * * * \\
(0.01692)\end{array}$ \\
\hline$N D T S_{i, t}$ & $\begin{array}{l}0.05969 * * \\
(0.02497)\end{array}$ & $\begin{array}{c}0.05023 \\
(0.05378)\end{array}$ & $\begin{array}{c}0.00507 \\
(0.05495)\end{array}$ \\
\hline$P R O F_{i, t}$ & $\begin{array}{c}-0.31443^{* * *} \\
(0.01042)\end{array}$ & $\begin{array}{c}-0.16798 * * * \\
(0.02339)\end{array}$ & $\begin{array}{l}-0.14221 * * * \\
(0.023857)\end{array}$ \\
\hline$S I Z E_{i, t}$ & $\begin{array}{c}0.38891 * * * \\
(0.01164)\end{array}$ & $\begin{array}{l}0.13958 * * * \\
(0.02353)\end{array}$ & $\begin{array}{l}0.18976 * * * \\
(0.02403)\end{array}$ \\
\hline$T A N G_{i, t}$ & $\begin{array}{l}-0.01727^{*} \\
(0.00997)\end{array}$ & $\begin{array}{l}0.05056 * * \\
(0.02179)\end{array}$ & $\begin{array}{l}-0.06925 * * \\
(0.02226)\end{array}$ \\
\hline$G O_{i, t}$ & $\begin{array}{l}-0.00227^{* *} \\
(0.00098) \\
\end{array}$ & $\begin{array}{l}-0.00239 \\
(0.00226)\end{array}$ & $\begin{array}{l}0.002585 \\
(0.00231)\end{array}$ \\
\hline$T A X_{i, t}$ & $\begin{array}{l}-0.00507 \\
(0.00344)\end{array}$ & $\begin{array}{c}-0.00071 \\
(0.00774)\end{array}$ & $\begin{array}{l}-0.007411 \\
(0.00791)\end{array}$ \\
\hline CONS & $\begin{array}{c}-0.48578 * * * \\
(0.01647)\end{array}$ & $\begin{array}{c}-0.19000 * * * \\
(0.04667)\end{array}$ & $\begin{array}{l}0.12063^{* * *} \\
(0.04770)\end{array}$ \\
\hline Observations & 11,645 & 11,645 & 11,645 \\
\hline $\mathrm{F}(\mathrm{N}(0.1))$ & $231.58 * *$ & $14.61 * *$ & $34.76 * *$ \\
\hline \multicolumn{4}{|l|}{$\mathrm{m} 1(\mathrm{~N}(0.1))$} \\
\hline \multicolumn{4}{|l|}{$\mathrm{m} 2(\mathrm{~N}(0.1))$} \\
\hline $\mathrm{R}^{2}$ & 0.2492 & 0.1292 & 0.1192 \\
\hline 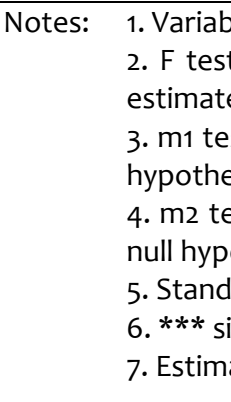 & $\begin{array}{l}\text { S are defined in Table } 1 . \\
\text { has normal distribution } \mathrm{N}(0,1) \\
\text { parameters. } \\
\text { is a test for first order autocor } \\
\text { is being no first order autocorre } \\
\text { t is a test for second order aut } \\
\text { hesis being no second order au } \\
\text { t deviations in brackets. } \\
\text { nificant at } 1 \% \text { significance; ** sig } \\
\text { ions include time dummy variak }\end{array}$ & $\begin{array}{l}\text { and tests the null hypothesis } \\
\text { relation of residuals and is dist } \\
\text { lation. } \\
\text { correlation of residuals and is } \\
\text { tocorrelation. } \\
\text { ificant at } 5 \% \text {; } \text { * significant at } 10\end{array}$ & $\begin{array}{l}f \text { overall insignificance of the } \\
\text { ibuted as } N(0,1) \text {, with the null } \\
\text { distributed as } N(0,1) \text {, with the } \\
\end{array}$ \\
\hline
\end{tabular}

Source: Authors.

According to the results presented in Table 4, the relationship between leverage and tangible assets depends on the type of debt. Tangible assets have a negative effect on total debt and short-term debt, but they have a positive effect on long-term debt. These results allow us to reject hypothesis 2, but we cannot reject hypothesis 3. The positive relationship between long-term debt and tangible assets suggests that small firms need collateral to mitigate the information asymmetry and agency problems these firms face in their relationships with creditors. Thus, SMEs with more assets in place are more likely to obtain long-term debt. SMEs without fixed assets have less collateral, and therefore tend to raise more short-term debt. These results suggest that SMEs are forced to borrow short-term debt, due to the impossibility of obtaining long-term debt on favourable conditions. Chittenden et al. (1996), Bevan and Danbolt (2004) and Matias ert al. (2015) obtain similar results for the relationship between tangible assets and leverage.

The empirical results show that the impact of liquidity on total debt and short-term debt is negative and statistically significant at the $1 \%$ level (Table 4). These results suggest that small firms with higher levels of liquidity have more long-term debt, but lower levels of 
total debt and short-term debt. These results are in accordance with the predictions of POT, i.e., firms with higher levels of liquidity have more internal funds, namely free cash flow, which they can use to fund their needs. Therefore, firms with greater liquidity borrow less. However, there is a positive and statistically significant relationship between liquidity and long-term debt. This result is consistent with the predictions of TOT, according to which firms with greater liquidity have greater debt capacity. On the basis of these results, we partially reject hypothesis 4. Michaelas et al. (1999) obtain positive relationships between liquidity and short-term, long-term and total debt.

Profitability is negatively related to leverage, providing evidence of POT, given that more profitable firms tend to use less total, long-term and short-term debt to fund their needs. Based on these results, we cannot reject hypothesis 5. The negative relationships between profitability and total, long-term and short-term debt suggest that small firms prefer internal to external finance. Small firms with higher levels of profitability have more internal funds available and need to borrow less. In addition, we find that profitability has a greater impact on long-term debt $(\beta=-0.16798)$ than on short-term debt $(\beta=-0.14221)$, suggesting that as internal funds become available, long-term debt will be the first type of leverage to be replaced. A negative relationship between profitability and leverage is also reported by various studies (Constand et al., 1991; Chittenden et al., 1996; Michaelas et al., 1999; Sogorb-Mira, 2005; Serrasqueiro et al., 2011; Degryse et al., 2012).

Growth opportunities have a negative and statistically significant relationship with total debt (Table 4). Therefore, we reject hypothesis 6 . This result suggests that firms with high levels of growth opportunities reduce their total debt. Roden and Lewellen (1995) conclude that growth opportunities have a negative and statistically significant relationship with total debt. These results are consistent with Heyman et al. (2008), but do not agree with the results of other studies about SMEs capital structure (Michaelas et al., 1999; Degryse et al., 2012).

The relationships between effective tax rate and total, short-term and long-term debt are not statistically significant. Therefore, the owners-managers of small firms do not appear to consider tax effects in their capital structure decisions. Consequently, our results do not provide support for hypothesis 7 formulated in the framework of TOT. Constand et al. (1991) and Michaelas et al. (1999) also identify no significant effects of corporate tax on level of leverage.

The results show there is a positive and statistically significant relationship between non-debt tax shields and total debt. This result contradicts TOT. Thus, we reject hypothesis 8. The results of the current study do not corroborate those of Jordan et al. (1998) and Michaelas et al. (1999), who identify a negative relationship between non-debt tax shields and total debt.

\section{Conclusion and implications}

In this paper, we analyse Portuguese small firms' determinants of debt, decomposing total debt in long and short-term debt. To reach the main objective of this study, we consider a sample of 2,329 small Portuguese firms for the period between 2007 and 2011. As method of estimation, we use fixed effects panel models. This study makes a contribution to the 
literature, given that the unit of analysis is small firms, unlike the majority of previous studies focusing on small and medium-sized firms.

Small firms face greater information asymmetry and agency problems with creditors, but the results regarding the relationships between determinant factors and those firms' capital structure seem to be similar to those identified by studies focusing on SMEs. In fact, the main conclusion of the current study is that the predictions of POT and TOT are followed by small firms in their capital structure, which is in accordance with the results of previous studies focusing on SMEs.

The empirical results of the current study provide various implications and suggestions for owners/managers and policy-makers. To small firms' owners/managers, we suggest establishing lasting and trusting relationships with creditors to mitigate asymmetric information and agency problems in order to obtain more favourable terms of credit. Considering the importance of small firms for the Portuguese economy, we suggest that policy-makers create special lines of credit and tax incentives to promote the growth of those firms that face difficulties in accessing external sources of finance.

To form a deeper understanding of capital structure decisions, we suggest future research should analyse small firms' capital structure decisions adopting a dynamic perspective, using dynamic estimators.

\section{References}

Ang, J.S. (1991). Small business uniqueness and the theory of financial management. Journal of Small Business Finance, 1 (1), 1-13.

Ang, J.S. (1992). On the theory of finance for privately held firms. Journal of Small Business Finance, 1 (3), 185-203.

Ang, J.S., Chua, J.H. \& McConnell, J.J. (1982). The administrative costs of corporate bankruptcy: A note. The Journal of Finance, 37 (1), 219-226. doi: 10.1111/j.1540-6261.1982.tb01104.x

Barnea, A., Haugen, R.A. \& Senbet, L.W. (1981). Market imperfections, agency problems, and capital structure: A review. Financial Management, 10 (3), 7-22.

Baskin, J. (1989). An empirical investigation of the pecking order hypothesis. Financial Management, $18(1), 26-35$.

Beck, T., Demirgüç-Kunt, A. \& Maksimovic, V. (2008). Financing patterns around the world: Are small firms different? Journal of Financial Economics, 89 (3), 467-487. doi: 10.1016/j.jfineco.2007.10.005

Beck, T., Demirgüç-Kunt, A., Laeven, L. \& Maksimovic, V. (2006). The determinants of financing obstacles. Journal of International Money and Finance, 25 (6), 932-952. doi: 10.1016/j.jimonfin.2006.07.005

Bevan, A.A. \& Danbolt, J. (2004). Testing for inconsistencies in the estimation of UK capital structure determinants. Applied Financial Economics, 14 (1), 55-66. doi: 10.1080/0960310042000164220

Bhaird, C. mac an \& Lucey, B. (2010). Determinants of capital structure in Irish SMEs. Small Business Economics, 35 (3), 357-375. doi: 10.1007/s11187-008-9162-6

Chittenden, F., Hall, G.C. \& Hutchinson, P.J. (1996). Small firm growth, access to capital markets and financial structure: Review of issues and an empirical investigation. Small Business Economics, 8 (1), 59-67. doi: 10.1007/BFo0391976

Commission of the European Communities (2003, 6 May). Commission Recommendation Nr. C(2003) 1422 concerning the definition of micro, small and medium-sized enterprises. Official Journal of the European Union, 2003/361/EC, L 124/36-L 124/41.

Constand, R.L., Osteryoung, J.S. \& Nast, D.A. (1991). Asset-based financing and the determinants of capital structure in small firm. In R. Yazdipour (Ed.), Advances in Small Business Finance of the series Financial and Monetary Policy Studies (vol. 21, pp. 29-45). Netherlands: Springer.

De Jong, A., Kabir, R. \& Nguyen, T.T. (2008). Capital structure around the world: The roles of firm and country - specific determinants. Journal of Banking \& Finance, 32 (9), 1954-1969. doi: 10.1016/j.jbankfin.2007.12.034 
DeAngelo, H. \& Masulis, R.W. (1980). Optimal capital structure under corporate and personal taxation. Journal of Financial Economics, 8 (1), 3-29. doi: 10.1016/0304-405X(80)90019-7

Degryse, H., Goeij, P. de \& Kappert, P. (2012). The impact of firm and industry characteristics on small firms' capital structure. Small Business Economics, 38 (4), 431-447. doi: 10.1007/s11187-010-9281-8

Donaldson, G. (1961). Corporate Debt Capacity: A Study of Corporate Debt Policy and the Determination of Corporate Debt Capacity. Division of Research, Harvard Graduate School of Business Administration, Boston.

Doove, S., Gibcus, P., Kwaak, T., Smit, L. \& Span T. (2014). Survey on the access to finance of enterprises (SAFE). Analytical Report 2014. Brussels: European Commission.

Fama, E.F. \& French, K.R. (2002). Testing trade-off and pecking order predictions about dividends and debt. Review of Financial Studies, 15 (1), 1-33. doi: 10.1093/rfs/15.1.1

Frank, M.Z. \& Goyal, V.K. (2008). Trade-off and pecking order theories of debt. In B.E. Eckbo (Ed.), Handbook of Empirical Corporate Finance (vol. 2, pp. 135-202). Amsterdam: Elsevier.

Gruber, M.J. \& Warner, J.B. (1977). Bankruptcy costs: Some evidence. Journal of Finance, 32 (2), 337347. doi: 10.1111/j.1540-6261.1977.tb03274.x

Grunert, J. \& Norden, L. (2012). Bargaining power and information in SME lending. Small Business Economics, 39 (2), 401-417. doi: 10.1007/s11187-010-9311-6

Gujarati, D.N. \& Porter, D.C. (2010/1992). Essentials of econometrics. $4^{\text {th }}$ edition. New York: McGrawHill/Irwin.

Hall, G.C., Hutchinson, P.J. \& Michaelas, N. (2000). Industry effects on the determinants of unquoted SMEs' capital structure. International Journal of the Economics of Business, 7 (3), 297-312. doi: 10.1080/13571510050197203

Hall, G.C., Hutchinson, P.J. \& Michaelas, N. (2004). Determinants of the capital structures of European SMEs. Journal of Business Finance \& Accounting, 31 (5-6), 711-728. doi: 10.1111/j.0306686X.2004.00554.x

Harris, M. \& Raviv, A. (1990). Capital structure and the informational role of debt. The Journal of Finance, 45 (2), 321-349. doi: 10.1111/j.1540-6261.1990.tb03693.x

Heshmati, A (2001). On the growth of micro and small firms: Evidence from Sweden. Small Business Economics, 17 (3), 213-228. doi: 10.1023/A:1011886128912

Heyman, D., Deloof, M. \& Ooghe, H. (2008). The financial structure of private held Belgian firms. Small Business Economics, 30 (3), 301-313. doi: 10.1007/s11187-006-9031-0

Holmes, S. \& Kent, P. (1991). An empirical analysis of the financial structure of small and large Australian manufacturing enterprises. Journal of Small Business Finance, 1 (2), 141-154.

Instituto Nacional de Estatística [National Statistical Institute] (2010). Empresas em Portugal 2008 [Data set]. Retrieved from https://www.ine.pt/xportal/xmain?xpid=INE\&xpgid=ine_publicacoes\&PUBLICACOESpub_boui= 87680294\&PUBLICACOESmodo=2

Jalilvand, A. \& Harris, R.S. (1984). Corporate behavior in adjusting to capital structure and dividend targets: An econometric study. The Journal of Finance, 39 (1), 127-145. doi: 10.1111/j.15406261.1984.tbo3864.x

Jensen, M.C. \& Meckling, W.H. (1976). Theory of the firm: Managerial behavior, agency costs and ownership structure. Journal of Financial Economics, 3 (4), 305-360. doi:10.1016/0304405X(76)90026-X

Jensen, M.C. (1986). Agency costs of free cash flow, corporate finance, and takeovers. American Economic Review, 76 (2), 323-329. doi: 10.2139/ssrn.99580

Jordan, J., Lowe, J. \& Taylor, P. (1998). Strategy and financial policy in UK small firms. Journal of Business Finance \& Accounting, 25 (1-2), 1-27. doi: 10.1111/1468-5957.00176

Kim, E.H. (1978). A mean-variance theory of optimal capital structure and corporate debt capacity. The Journal of Finance, 33 (1), 45-63. doi: 10.1111/j.1540-6261.1978.tb03388.x

Kraus, A. \& Litzenberger, R.H. (1973). A state-preference model of optimal financial leverage. The Journal of Finance, 28 (4), 911-922. doi: 10.1111/j.1540-6261.1973.tb01415.x

López-Gracia, J. \& Aybar-Arias, C. (2000). An empirical approach to the financial behaviour of small and medium sized companies. Small Business Economics, 14 (1), 55-63. doi: 10.1023/A:1008139518709

López-Gracia, J. \& Sánchez-Andújar, S. (2007). Financial structure of the family business: Evidence from a group of small Spanish firms. Family Business Review, 20 (4), 269-287. doi: 10.1111/j.17416248.2007.00094.x 
López-Gracia, J. \& Sogorb-Mira, F. (2008). Testing trade-off and pecking order theories financing SMEs. Small Business Economics, 31 (2), 117-136. doi: 10.1007/s11187-007-9088-4

MacKie-Mason, J.K. (1990). Do taxes affect corporate financing decisions? The Journal of Finance, 45 (5), 1471-1493. doi: 10.1111/j.1540-6261.1990.tb03724.x

Matias, F., Baptista, C. \& Salsa, L. (2015). Estrutura do capital das PME da indústria transformadora portuguesa: Uma análise com dados em painel. Tourism \& Management Studies, 11 (2), 120-129. doi: $10.18089 / \mathrm{tms} .2015 .11215$

Michaelas, N., Chittenden, F. \& Poutziouris, P. (1999). Financial policy and capital structure choise in U.K. SMEs: Empirical evidence from company panel data. Small Business Economics, 12 (2), 113130. doi: $10.1023 / A: 1008010724051$

Modigliani, F. \& Miller, M.H. (1958). The cost of capital, corporation finance and the theory of investment. The American Economic Review, 48 (3), 261-297.

Modigliani, F. \& Miller, M.H. (1963). Corporate income taxes and the cost of capital: A correction. The American Economic Review, 53 (3), 433-443.

Myers, S.C. \& Majluf, N.S. (1984). Corporate financing and investment decisions when firms have information that investors do not have. Journal of Financial Economics, 13 (2), 187-221. doi: 10.1016/0304-405X(84)90023-0

Myers, S.C. (1977). Determinants of corporate borrowing. Journal of Financial Economics, 5 (2), 147175. doi: 10.1016/0304-405X(77)90015-0

Myers, S.C. (1984). The capital structure puzzle. The Journal of Finance, 39 (3), 574-592. doi: 10.1111/j.1540-6261.1984.tb03646.x

Myers, S.C. (1993). Still searching for optimal capital structure. Journal of Applied Corporate Finance, 6 (1), 4-14. doi: 10.1111/j.1745-6622.1993.tbo0369.x

Pettit, R.R. \& Singer, R.F. (1985). Small business finance: A research agenda. Financial Management, 14 (3), $47-60$.

Psillaki, M. \& Daskalakis, N. (2009). Are the determinants of capital structure country or firm specific? Small Business Economics, 33 (3), 319-333. doi: 10.1007/s11187-008-9103-4

Ramalho, J.J.S. \& Silva, J.V. da (2009). A two-part fractional regression model for the capital structure decisions of micro, small, medium and large firms. Quantitative Finance, 9 (5), 621-636.

Robichek, A.A. \& Myers, S.C. (1966). Problems in the theory of optimal capital structure. Journal of Financial and Quantitative Analysis, 1 (2), 1-35. doi: 10.2307/2329989

Roden, D.M. \& Lewellen, W.G. (1995). Corporate capital structure decisions: Evidence from leveraged buyouts. Financial Management, 24 (2), 76-87.

Scott Jr, J.H. (1976). A theory of optimal capital structure. The Bell Journal of Economics, 7 (1), 33-54. doi: $10.2307 / 3003189$

Serrasqueiro, Z.S., Armada, M.R. \& Nunes, P.M. (2011). Pecking order theory versus trade-off theory: Are service SMEs' capital structure decisions different? Service Business, 5, 381-409. doi: 10.1007/s11628-011-0119-5

Shyam-Sunder, L. \& Myers, S.C. (1999). Testing static tradeoff against pecking order models of capital structure. Journal of Financial Economics, 51 (2), 219-244. doi: 10.1016/S0304$405 \times(98) 00051-8$

Smith Jr., C.W. \& Warner, J.B. (1979). Bankruptcy, secured debt, and optimal capital structure: Comment. The Journal of Finance, 34 (1), 247- 251. doi: 10.1111/j.1540-6261.1979.tb02085.x

Sogorb-Mira, F. \& López-Gracia, J. (2003). Pecking order versus trade-off: An empirical approach to the small and medium enterprise capital structure. doi: 10.2139/ssrn.393160

Sogorb-Mira, F. (2005). How SME uniqueness affects capital structure: Evidence from a 1994-1998 Spanish data panel. Small Business Economics, 25 (5), 447-457. doi: 10.1007/s11187-004-6486-8

Stulz, R.M. (1990). Managerial discretion and optimal financing policies. Journal of Financial Economics, 26 (1), 3-27. doi: 10.1016/0304-405X(90)90011-N

Taggart Jr., R.A. (1977). A model of corporate financing decisions. The Journal of Finance, 32 (5), 14671484. doi: 10.1111/j.1540-6261.1977.tb03348.x

Wooldridge, J.M. (2002). Econometric analysis of cross section and panel data. Cambridge: The MIT Press. 
Zélia SerRAsqueiro is full Professor of Department Management and Economics of University of Beira Interior (UBI) and researcher in the unit CEFAGE - Center for Advanced Studies in Management and Economics-UBI. She is author of articles in several international journals: Entrepreneurship Theory \& Practice, European Journal of Finance, Journal of Evolutionary Economics, Small Business Economics, Industrial and Corporate Change, Journal of Business Research, Journal of Service Management, Long Range Planning, Management Research Review, Research Policy, Social Responsibility Journal, Review of Accounting and Finance, Services Industries Journal. Institutional address: Centro de Estudos e Formação Avançada em Gestão e Economia (CEFAGE) e Universidade da Beira Interior, Departamento de Gestão e Economia, Polo IV, Estrada do Sineiro, 6200-209 Covilhã.

Fernanda Matias is Professor at the School of Management, Hospitality and Tourism of the University of Algarve and researcher in the unit CEFAGE - Center for Advanced Studies in Management and Economics-UAlg. She was Vice-rector of University of Algarve. She has taught graduate and undergraduate courses in Management and Finance. Her research interests are in the theoretical and practical aspects of the field of Finance. She is the co-author of the book Financial of Enterprises, Texto Editora, Lisbon. Institutional address: Centro de Estudos e Formação Avançada em Gestão e Economia (CEFAGE) e Universidade do Algarve, Escola Superior de Gestão, Hotelaria e Turismo (ESGHT), Campus da Penha, 8000-117 Faro.

LEONOR SALSA is Professor at the School of Management, Hospitality and Tourism of the University of Algarve and researcher in the unit CEFAGE - Center for Advanced Studies in Management and Economics-UAlg. She is director of the post-graduate course in Real Estate Evaluation and Activity Management and teaches, guides and argues dissertation works in several master's degrees Accounting, Corporate Finance, Hotel Management and Taxation. She is dedicated to the research and publication in the field of Corporate Finance and Tourism. Institutional address: Centro de Estudos e Formação Avançada em Gestão e Economia (CEFAGE) e Universidade do Algarve, Escola Superior de Gestão, Hotelaria e Turismo (ESGHT), Campus da Penha, 8000-117 Faro.

Submitted 17 February 2016

Accepted 20 April 2016 